\title{
PROFESSOR PACKARD'S “LAMARCK, HIS LIFE AND WORK.”
}

\author{
BY ROBERT T. JACKSON.
}

The late Professor Packard laid naturalists under deep obligations by his full and painstaking Life of Lamarck, the only adequate account of the great French naturalist. Professor Packard gives all that he could gather by careful search in regard to his family and early life, his struggles with poverty, his activities in numerous lines of scientific work, and a careful consideration of what he accomplished in these several lines. The relations of Lamarck to his contemporaries in his work and thought is forcibly brought out and numerous extracts from Lamarck's writings show what his views were on physical and biological problems, especially evolution. The book is full of evidences of a loving care and reverence for the great master and effort to do full credit to him for his advanced views and what he accomplished.

In respect for Professor Packard's memory it is of interest to record here some of the leading features he brought out in his life of Lamarck, which from the human and scientific aspects should be of exceptional interest to all biologists.

The Life of Lamarck is the old old story of a man of genius who lived far in advance of his age, and died comparatively unappreciated and neglected. The factors of evolution as stated by Lamarck, it is now claimed by many really comprise the primary or foundation principles, or initiative causes, of the origin of life-forms.

Lamarck was born I August 1 744, and died in Paris 28 December 1829 , at the age of eighty-five years. The youngest of eleven children, throughout his life he struggled with poverty and during the last of his life for some ten years was partially, then wholly blind, although married four times he died a widower. A devoted daughter soothed his last years and acting as amanuensis gave to the world some of his important publications.

As a youth Lamarck entered the army which, owing to an injury, he early abandoned. Music, medicine and science drew his attention and he worked in a bank. When twenty-five years of age he devoted himseif to botany and science thereafter claimed his entire life. For about twenty-five years he pursued botany and in $177^{8}$ published the Flore Frincaise, a three volume work, he also published other botanical works and was connected with the Jardin des Plantes as Keeper of the herbarium. 
In 1793 Lamarck, then in his fiftieth year, assumed the duties of his professorship of the zoilogy of invertebrate animals, and with the vigor of an intellectual giant took up new labors in an untrodden field both in pure science and philosophic thought. Already extensive collections had accumulated at the Paris museum and to Lamarck fell the task of arranging and classifying them as well as teaching. The result of his studies in this liner was his great work in seven volumes known under the title Animaux sans Vertebres, the first volume appearing in $180 \mathrm{r}$, and the last, or seventh, in 1822 .

Besides botany and zoology Lamarck studied and published on the sciences of meteorology, physics, chemistry, geology and palæontology. When a medical student in Paris he studied the clouds from his attic window and (as Professor Ward informs me) published the first classification of clouds. $\mathrm{He}$ was the first one to foretell the probabilities of the weather, thus anticipating by half a century the modern idea of making the science of meteorology of practical use to mankind. From 1799 to 1810 he regularly published an annual meteor. ological report containing the statement of probabilities acquired by a long series of observations.

In palæontology he did pioneer work, he combats the view that fossils are extinct species and that the earth has passed through a general catastrophe, but urges that species have changed as a result of time, and that fossil forms are the ancestors of animals now living. In the first published expression of his views on palæontology in 1801 we find the following truths enumerated on which the science is based: (1) The great length of geological time: (2) The continuous existence of animal life all through the different geological periods without sudden extinctions and as sudden recreations of new assemblages: (3) The physical environment remaining practically the same throughout in general, but with (4) continual, gradual but not catastrophic changes in the relative distribution of land and sea and other modifications in the physical geography, changes which (5) caused corresponding changes in the habitat and (6) consequently in the habits of the living beings; so that there has been all through geological history a slow modification of life-forms. Professor Packard therefore enters the claim that Lamark was one of the chief founders of palæontology and the first French author of a detailed palæontological work. It must be ad. mitted that the statement generally made that Cuvier was the founder of this science must be modified though he may be regarded as the chief founder of vertebrate as Lamarck was of invertebrate palæontology.

Lamarck was a uniformitarian in his views of geology and biology in contradistinction to Cuvier who was a catastrophist. Lamarck contended that 
species were descended from others, Cuvier that they were permanent.

Lamarck was the master mind of the period of systematic zoology. His tabular view of the classes of the animal kingdom was to his mind a genealogical tree. His idea of the animal kingdom anticipated and was akin to that of our day. He may be said to have had a wonderfully good eye for genera. $\mathrm{He}$ founded the classes of Crustacea, Arachnida, Radiata (echinoderms as separate from polyps), placed the sponges (as did (uvier) with the polyps and separated the ascidians from the mollusks.o

Lamarck long believed that species were constant in nature. Evidence goes to show that he changed his views at or soon after 1793 , when he entered on his zoölogical work. His first published statements on evolution were in 1801 in the preface of his Systeme des Animaux sans Vertèbres, he being then about fifty-seven years of age. He there maintains that Nature began with the most simply organized "then with the aid of much time and of favorable circumstances she formed all the others." Again "I could prove that it is not the form either of the body or of its parts which gives rise to habits, to the mode of life of animals, but, on the contrary, it is the habits, the mode of life, and all the influential circumstances which have, with time, made up the form of the body and of the parts of the animals. With the new forms new faculties have been acquired, and gradually nature has reached the state in which we actually see her."

One who has read the writings of the great naturalist, who may well be regarded as the founder of evolution, will readily realize that Lamark's mind was essentially philosophic, comprehensive and synthetic. He looked upon every problem in a large way.

"In Lamarck, at the opening of the past century, we behold the spectacle of a man devoting over fifty years of his life to scientific research in biology, and insisting on the doctrine of spontaneous generation; of the immense length of geological time, so opposed to the views held by the Church; the evolution of plants and animals from a single germ, and even the origin of man from the apes, yet as earnestly claiming that nature has its Author who in the begirning established the order of things, giving the initial impulse to the laws of the universe."

In the last chapter of his book Professor Packard deals with the revival of Lamarckian views in the school of Neolamarckians, dating from about I 866 and especially active in this country. Prominent in this school were Herbert Spencer, Hyatt, Cope and Packard. Hyatt and Packard, students of Agassiz's, and life long friends, both of distinctly philosophical minds did much by their researches to further the adoption of Lamarckian views with which they were in warm sympathy.

NOTE.-Mrs. Packard has a number of ref rints of Dr. Packard's recent paper on "The Origin of the Markings of Organisms, etc.." (see Index to Periodical Literature) for the distributinn of which he left no mailing list. Those. who desire copies of the paper are invited to notify her, at 275 Angell St.. Prov Jence, R. I. 

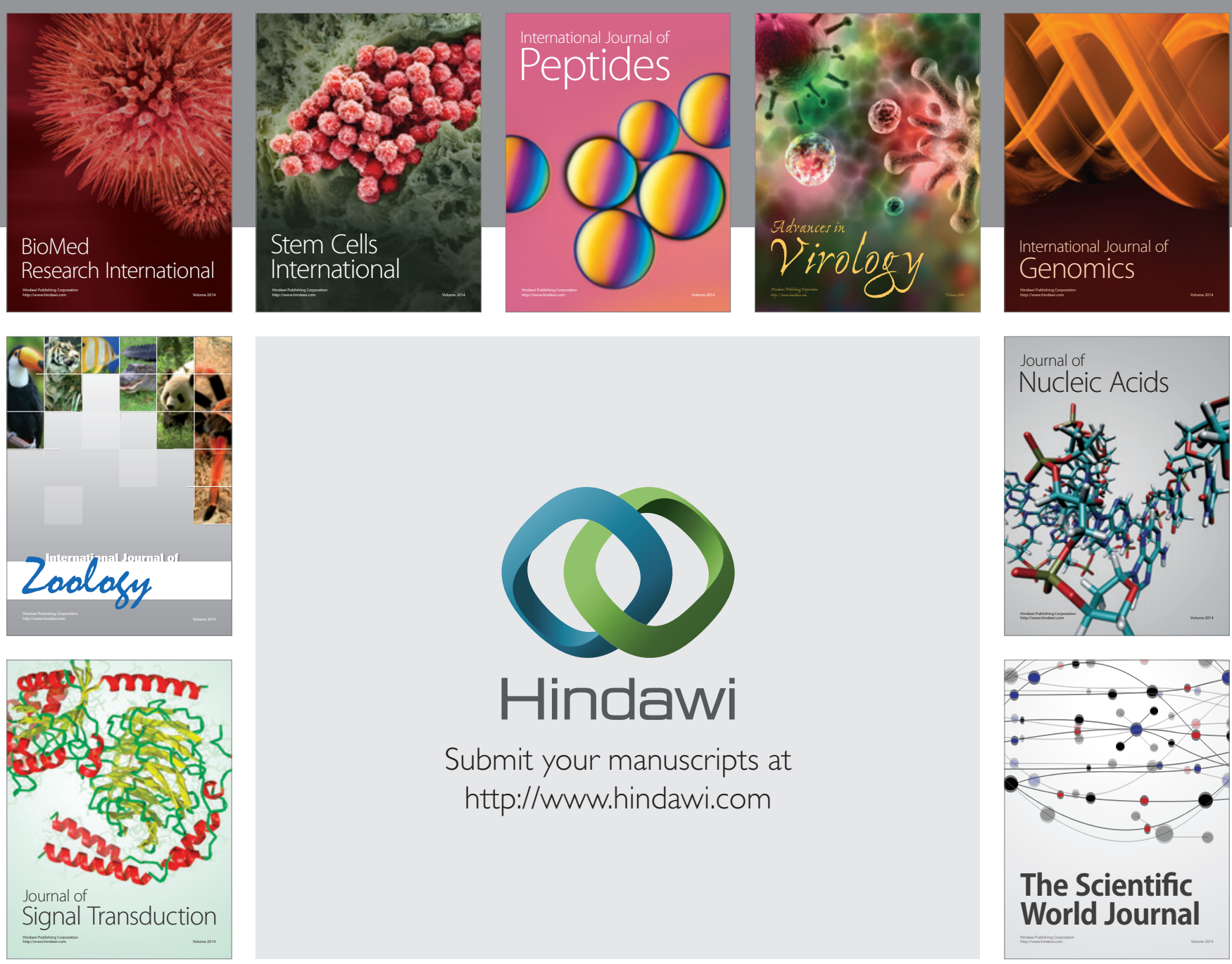

Submit your manuscripts at

http://www.hindawi.com
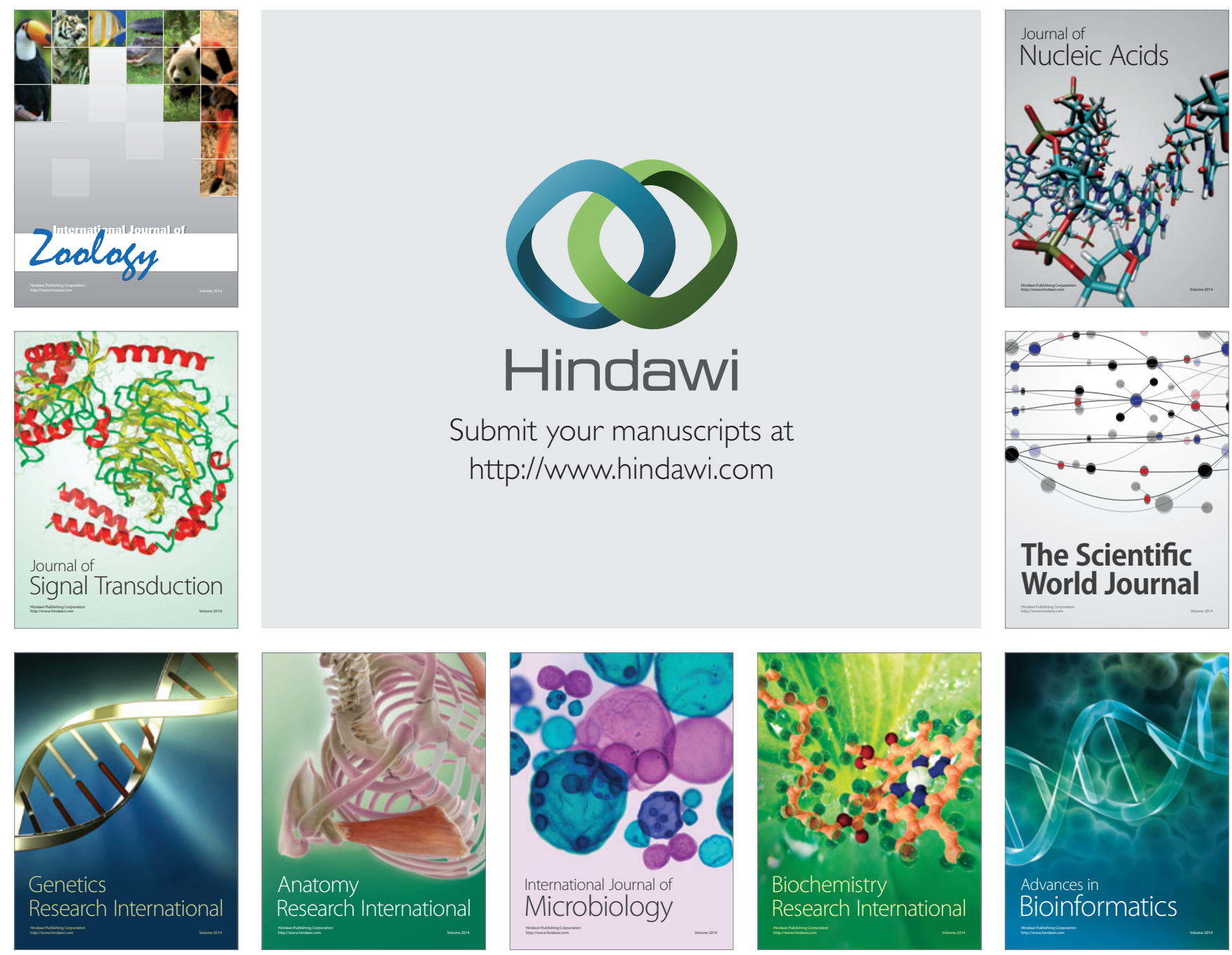

The Scientific World Journal
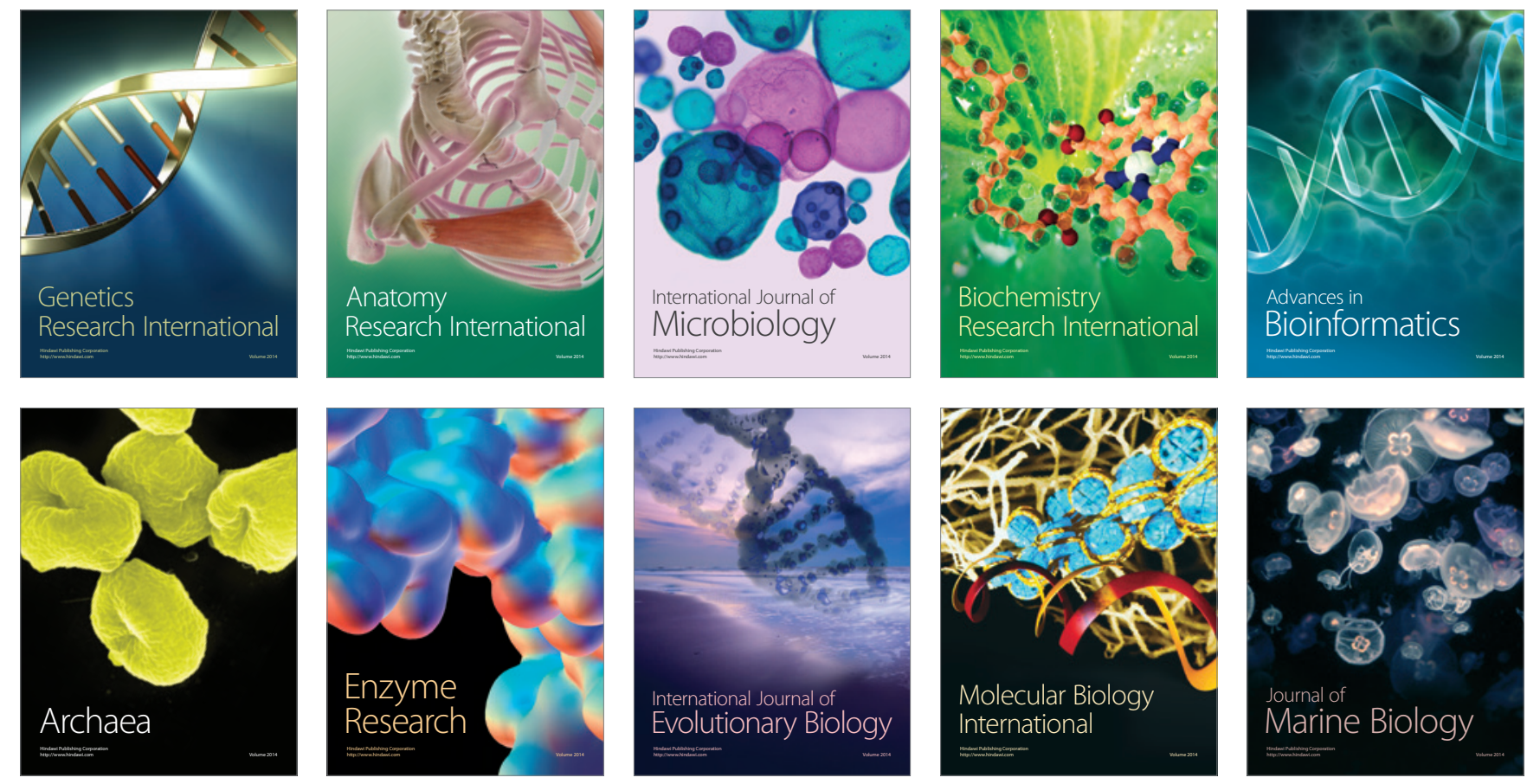